\title{
Arbeidsmarktintrede en vroege beroepsloopbaan van schoolverlaters in Nederland, 1986-2002
}

\author{
Maarten H.J. Wolbers*
}

\begin{abstract}
Het doel van dit artikel is om de gevolgen van arbeidsmarktflexibilisering in Nederland te bestuderen voor jongeren die sinds het midden van de jaren tachtig van de vorige eeuw de arbeidsmarkt hebben betreden. De nadruk ligt op schoolverlaters, omdat vooral zij - als gevolg van het ontbreken van relevante werkervaring - met flexibele arbeid worden geconfronteerd in de wedijver om beschikbare banen met zittende werknemers. De arbeidsmarktintrede is onderzocht aan de hand van de kans op werkloosheid en de kans op een tijdelijke aanstelling. De vroege beroepsloopbaan is bestudeerd in termen van baanverlies en beroepsmobiliteit. Het OSA Arbeidsaanbodpanel is gebruikt voor de empirische analyse. Op basis van deze panelstudie zijn schoolverlaters geselecteerd die het onderwijs zijn uitgestroomd in de periode 1986-2002. De resultaten laten zien dat de flexibilisering van de Nederlandse arbeidsmarkt een succesvol wapen is geweest in de strijd tegen de hoge jeugdwerkloosheid. Tegelijkertijd echter is de kans op een tijdelijke aanstelling aanzienlijk toegenomen onder schoolverlaters. Voor een dergelijke arbeidsrelatie geldt dat deze relatief vaak eindigt in baanverlies.
\end{abstract}

Trefwoorden: jeugdwerkloosheid, flexibele arbeid, arbeidsmarktintrede, schoolverlaters

\section{Inleiding}

De crisis in de wereldeconomie van de jaren zeventig van de vorige eeuw heeft het ideaal van volledige werkgelegenheid doen verdwijnen. Hoge werkloosheid en inactiviteit hebben ertoe geleid dat arbeidsorganisaties vroegen en vragen om een flexibele arbeidsmarkt (Córdova, 1986). Als gevolg daarvan is de standaard van life-time employment, een levenslange baan bij dezelfde werkgever, aan erosie onderhevig geraakt en zijn verschillende vormen van flexibele arbeid (zoals tijdelijke aanstellingen) opgekomen (Kalleberg, 2000). Daarnaast heeft de globalisering bijgedragen aan de flexibilisering van de arbeidsmarkt in moderne, (post)industriële samenlevingen (Castells, 2000). Zowel door de verspreiding van informatietechnologie als door reorganisaties op de werkplek is de vraag naar arbeid steeds meer verschoven van laag- naar hooggeschoold werk. Met name in Europa, waar arbeidsmarkten een stuk meer rigide zijn in vergelijking met bijvoorbeeld de Verenigde Staten, is dit proces van skills upgrading 'opgelost' door hoge werkloosheid en de toewijzing van een toenemend aantal werknemers in tijdelijke arbeidscontracten (DiPrete, 2005).

Ondanks deze gemeenschappelijke structurele omstandigheden zijn er aanzienlijke verschillen tussen landen als het gaat om de ontwikkeling in het aandeel flexibele arbeid in de totale werkgelegenheid (De Grip et al., 1997; OECD, 2002). Verschillen in gevoerd arbeidsmarktbeleid en historisch gegroeide institutionele configuraties bepalen de mate waarin de beroepbevolking van een land wordt blootgesteld aan flexibilisering en de daarmee gepaard gaande onzekerheid in de loop van het globaliseringsproces (Mills \& Blossfeld, 2005). Vooral jongeren die voor het eerst de arbeidsmarkt betreden, worden geconfronteerd met deze onzekerheid, omdat schoolverlaters in hun positie als outsiders zonder relevante werkervaring wedijveren om de beschikbare posities op de arbeidsmarkt met degenen die al een stabiele arbeidsmarktpositie hebben verworven (insiders) (De Vreyer et al., 2000). De meest belangrijke institutionele factoren voor wat betreft de integratie van jongeren op de

* Maarten H.J. Wolbers is verbonden aan de sectie Sociologie van de Radboud Universiteit Nijmegen. Correspondentieadres: Sectie Sociologie, Faculteit der Sociale Wetenschappen, Radboud Universiteit Nijmegen, Postbus 9104, 6500 HE Nijmegen. E-mail: m.wolbers@maw.ru.nl. 
arbeidsmarkt hebben betrekking op werkgelegenheidsbeschermende wet- en regelgeving, de beroepsgerichtheid van het onderwijssysteem en het type welvaartstaat (Breen \& Buchmann, 2002).

Het doel van dit artikel is om de gevolgen van arbeidsmarktflexibilisering in Nederland te bestuderen voor jongeren die sinds het midden van de jaren tachtig van de vorige eeuw voor het eerst de arbeidsmarkt hebben betreden. De arbeidsmarktintrede is onderzocht aan de hand van de kans op werkloosheid en de kans op een tijdelijke aanstelling. De vroege beroepsloopbaan is bestudeerd in termen van baanverlies en beroepsmobiliteit. Het OSA Arbeidsaanbodpanel is gebruikt voor de empirische analyse. Deze panelstudie met gedetailleerde informatie over (veranderingen in) de arbeidsmarktpositie van de (potentiële) beroepsbevolking in Nederland is gestart in 1985, met herhaalde metingen die om het jaar plaatsvinden sinds 1986. Op basis hiervan zijn 1.008 schoolverlaters geselecteerd die in de periode 1986-2002 het onderwijs zijn uitgestroomd.

\section{Flexibilisering van de Nederlandse arbeidsmarkt}

Nederland is een interessant geval als het gaat om het bestuderen van de effecten van arbeidsmarktflexibilisering voor jongeren aan het begin van hun beroepsloopbaan. Als gevolg van de hoge (jeugd)werkloosheid aan het begin van de jaren tachtig van de vorige eeuw is een aantal actieve arbeidsmarktmaatregelen genomen om de Nederlandse arbeidsmarkt flexibeler te maken. Het Akkoord van Wassenaar uit 1982 wordt daarbij beschouwd als basis voor deze initiatieven en het vormt een van de pijlers van het Nederlandse poldermodel (Visser \& Hemerijck, 1997). In de eerste plaats heeft de overheid de ontslagbescherming van zittende werknemers wat afgezwakt. Enerzijds werden ontslagprocedures aangepast; anderzijds werden voorwaarden voor het gebruik van tijdelijke contracten versoepeld. Desondanks is de mate van deregulering van werkgelegenheidsbeschermende maatregelen in Nederland gering geweest (OECD, 1999). Nederland heeft nog steeds een invloedrijke vakbeweging (hoewel vakbondslidmaatschap relatief laag is), kent een gecoördineerde loononderhandelingsstructuur, heeft een beroepsbevolking die voor het overgrote deel valt onder een of andere cao en kende tot 2006 een senioriteitsprincipe waarbij geldt dat degene met het kortste dienstverband het eerst wordt ontslagen (last in, first out). In de tweede plaats zijn werkgevers uitzend- en afroepwerk gaan gebruiken om (tijdelijke) productieaanpassingen in hun bedrijf of organisatie op te vangen als gevolg van economische groei of krimp. In Nederland heeft deze vorm van flexibele arbeid zo'n vlucht genomen dat in de loop van de jaren negentig van de vorige eeuw uitzend- en afroepkrachten het grootste deel van de flexwerkers betreffen (OECD, 2002).

Als gevolg van deze maatregelen ten behoeve van arbeidsmarktflexibilisering is de banengroei in Nederland sterk gestegen. Tussen 1983 en 1997 is het aantal banen met gemiddeld 1,8\% gestegen per jaar; een groeipercentage dat vier keer hoger is dan het EU-gemiddelde (OECD, 1998). Deze banengroei is voor het overgrote deel het resultaat van de toename in flexibele arbeid. Feitelijk kende Nederland de hoogste stijging in flexibele arbeid in de EU in de periode 1985-1995 (De Grip et al., 1997). Deze toename in flexibele arbeid is vooral gerelateerd aan de enorme stijging in deeltijdwerk, dat in Nederland niet noodzakelijkerwijs de kenmerken bezit van een onzekere arbeidsmarktsituatie (Meulders et al., 1994). Deeltijdwerk kan hier zeker niet worden beschouwd als marginale arbeid, in tegenstelling tot sommige andere Europese landen en de Verenigde Staten. Veel deeltijdbanen betreffen vaste aanstellingen, ze zijn vaak vrijwillig gekozen en beschermen in dezelfde mate als voltijdbanen tegen onbillijk ontslag (Remery et al., 2002). Daarnaast is de sterke stijging van deeltijdarbeid in Nederland nauw verbonden aan de late en snelle komst van (gehuwde) vrouwen op de arbeidsmarkt en het gebrek aan voldoende faciliteiten voor kinderopvang (Visser, 2002). 
Desalniettemin kan deeltijdwerk worden beschouwd als een strategie van arbeidsmarktflexibilisering en als een instrument voor herverdeling van werkgelegenheid.

In 1999 is de Wet Flexibiliteit en Zekerheid ('Flexwet') van kracht geworden, met als doel enerzijds de flexibiliteit van de arbeid, de arbeidsorganisatie en de arbeidsrelaties te vergroten en anderzijds meer werk- of bestaanszekerheid te verschaffen voor (in het bijzonder zwakke) groepen op en buiten de arbeidsmarkt (Wilthagen, 1998). ${ }^{1}$ Zo is uitzendwerk sindsdien aan minder voorwaarden verbonden (de vergunningplicht voor uitzendbureaus, bijvoorbeeld, is ingetrokken en de maximale uitzendtermijn is afgeschaft), terwijl tegelijkertijd meer bescherming wordt geboden aan individuele werknemers die via een uitzendbureau aan het werk zijn (zo wordt de uitzendovereenkomst voortaan beschouwd als een arbeidsovereenkomst). Het achterliggende idee van flexicurity is dat - gegeven de rol die arbeidsmarktinstituties spelen - de balans tussen flexibiliteit en zekerheid meer effectief in stand kan worden gehouden door activering van zowel werkgevers als werknemers (Muffels \& Luijkx, 2006). Het centrale element is hier de kennissamenleving. Investeringen in menselijk kapitaal gedurende de gehele levensloop (levenslang leren) waarborgen de multi-inzetbaarheid en flexibiliteit van werknemers, wat hun kans om aan het werk te blijven vergroot gedurende de beroepsloopbaan. Het is de vraag overigens of dit ook daadwerkelijk werkt, omdat bekend is dat werknemers liever in scholingsactiviteiten voor hoger dan lager opgeleiden investeren (Wolbers, 2005a), wat wellicht eerder leidt tot meer dan minder marginalisering van de zwakste groepen op de Nederlandse arbeidsmarkt, voor wie flexicurity met name bedoeld is.

\section{Arbeidsmarktintrede en vroege beroepsloopbaan van schoolverlaters in Nederland}

Recent onderzoek heeft laten zien dat de bescherming van de rechtspositie van zittende werknemers en de beroepsgerichtheid van het onderwijssysteem - dat wil zeggen de mate waarin het duidelijke signalen afgeeft aan werkgevers over de beroepsspecifieke kennis en vaardigheden die scholieren in het (beroeps)onderwijs aanleren - belangrijke institutionele factoren zijn voor het verklaren van verschillen in arbeidsmarktintegratie van schoolverlaters tussen landen (Wolbers, 2005b). De kans op werkloosheid en de kans op een tijdelijke aanstelling zijn daarbij gebruikt als indicatoren voor de mate van arbeidsmarktintegratie. Als wordt vergeleken met andere Europese landen, dan is de positie van Nederland relatief gunstig. Gemiddeld genomen zit slechts zo'n $5 \%$ van de schoolverlaters in Nederland zonder werk, net zoals dit het geval is in Oostenrijk en Denemarken. Ook het aandeel schoolverlaters met een tijdelijke aanstelling is vergeleken met andere landen laag in Nederland. Naast relatief gunstige macro-economische omstandigheden is het vooral de beroepsgerichtheid van het Nederlandse onderwijssysteem die de goede prestaties van Nederland verklaren.

In dit artikel wordt daarom begonnen de arbeidsmarktintrede van schoolverlaters in Nederland te bestuderen aan de hand van hun kans op werkloosheid en vervolgens - indien zij betaald werk hebben gevonden - hun kans op een tijdelijke aanstelling. De kans op een deeltijdaanstelling is niet onderzocht, alhoewel het ongetwijfeld onderdeel is van de flexibilisering van de Nederlandse arbeidsmarkt. De reden daarvoor is dat het - zoals hiervoor is beargumenteerd - veel meer is gerelateerd aan de toegenomen arbeidsmarktdeelname van vrouwen dan aan pogingen om de hoge (jeugd)werkloosheid te bestrijden. ${ }^{2}$

Vervolgens worden de gevolgen van arbeidsmarktflexibilisering voor de vroege beroepsloopbaan onderzocht, zowel in termen van baanverlies als in termen van opwaartse en neerwaartse beroepsmobiliteit. De centrale vraag is hier of een tijdelijke aanstelling bij intrede op de arbeidsmarkt een valstrik is waarbij periodes van werk en werkloosheid elkaar afwisselen, dan wel een opstap naar een stabiele arbeidsmarktpositie. In het laatste geval 
zijn de gevolgen van flexibilisering van tijdelijke aard en daarmee minder problematisch. Het geringe aantal studies over dit onderwerp lijkt dit (vooralsnog) te bevestigen. Bevindingen voor Duitsland, het Verenigd Koninkrijk en Italië laten zien dat een tijdelijke aanstelling bij arbeidsmarktintrede (op de lange termijn) de beroepsloopbaan niet benadeelt, ondanks dat tijdelijk werk tijdens de vroege beroepsloopbaan gepaard gaat met meer perioden van werkloosheid (McGinnity et al., 2005; Scherer, 2004). Op overeenkomstige wijze hebben Steijn et al. (2006) onlangs voor Nederland de langetermijneffecten van de arbeidsmarktintrede onderzocht. Ook zij concluderen dat personen die hun loopbaan startten als werkloos of werkend in een tijdelijke aanstelling een grotere kans hebben op latere werkloosheid. Tegelijkertijd echter vonden zij dat - in overeenstemming met de hypothese dat flexibele arbeid een opstap is naar een stabiele arbeidsmarktpositie - jonge werknemers met een tijdelijke aanstelling vaker opwaarts mobiel zijn. ${ }^{3}$ Daarnaast is voor Nederland bekend dat het aanvangssalaris van schoolverlaters met een flexibele arbeidsrelatie lager is dan dat van degenen met een reguliere aanstelling (De Vries \& Wolbers, 2005). Een groot deel van dit beloningsverschil kan worden toegeschreven aan verschillen in het bereikte opleidingsniveau van schoolverlaters en de daarmee gepaard gaande kans om in het primaire versus secundaire segment van de arbeidsmarkt terecht te komen.

\section{Hypothesen}

Het bereik van de empirische analyse die volgt in dit artikel start in het midden van de jaren tachtig van de vorige eeuw. Deze periode werd gekenmerkt door een hoge jeugdwerkloosheid als gevolg van de economische crisis waarin de Nederlandse arbeidsmarkt die tijd gevangenzat. De jeugdwerkloosheid bereikte haar hoogtepunt in 1984 met 25\% (Salverda, 1992). Arbeidsmarktflexibilisering werd als een belangrijk wapen beschouwd om de strijd aan te binden met deze hoge werkloosheid. In de veronderstelling dat het gevoerde actieve arbeidsmarktbeleid het beoogde effect heeft gehad, verwacht ik dat de kans op werkloosheid voor schoolverlaters sindsdien flink is gedaald. Tegelijkertijd echter heeft het gevoerde beleid vanzelfsprekend geleid tot een grotere kans op een tijdelijke aanstelling bij arbeidsmarktintrede. Als het gaat om de gevolgen van flexibele arbeid voor de latere beroepsloopbaan, benadrukken de meeste onderzoekers vooral de negatieve gevolgen ervan (zie bijv. Kalleberg et al., 2000). Ook ik doe dat hier. Ik veronderstel dat een tijdelijke aanstelling bij arbeidsmarktintrede een negatief effect heeft op het verloop van de beroepsloopbaan van individuen - wellicht niet permanent, maar in ieder geval aan het begin van de loopbaan in termen van zowel baanverlies als promotieperspectief. Samengevat luidt de algemene hypothese van dit artikel als volgt:

De flexibilisering van de Nederlandse arbeidsmarkt sinds het midden van de jaren tachtig van de vorige eeuw heeft weliswaar geleid tot een lagere werkloosheid onder schoolverlaters, maar tegelijkertijd tot meer flexibele arbeid bij hun arbeidsmarktintrede, wat vergezeld gaat met een groter risico op baanverlies en een geringer promotieperspectief tijdens de vroege beroepsloopbaan.

Naast deze hypothese beschouw ik standaard sociologische factoren van belang bij het verklaren van arbeidsmarktkansen van schoolverlaters. In de eerste plaats speelt opleiding natuurlijk een belangrijke rol. Over het algemeen hebben hoger opgeleide schoolverlaters betere arbeidsmarktkansen dan lager opgeleide schoolverlaters. Dit geldt niet alleen voor de kans op werk, maar ook voor de kwaliteit van het werk. Bovendien is - binnen niveaus het onderscheid tussen algemeen vormende en beroepsgerichte opleidingen van belang. Met name als het gaat om de kans op betaald werk en de kans op een passende baan wordt verondersteld dat schoolverlaters van het beroepsonderwijs betere perspectieven hebben dan degenen met (alleen) algemeen vormend onderwijs, omdat werkgevers vaak op de hoogte zijn van en vertrouwen kunnen op de beroepsgerichte kennis en vaardigheden die zijn opgedaan in het beroepsonderwijs (Shavit \& Müller, 2000). 
In de tweede plaats heeft sekse een invloed op arbeidsmarktkansen. Vrouwen hebben over het algemeen geringere vooruitzichten op de arbeidsmarkt dan mannen, omdat eerstgenoemden hun beroepsloopbaan vaak combineren met huishoudelijke taken en de opvoeding van kinderen (Blossfeld \& Hakim, 1997). Hoewel dit artikel betrekking heeft op schoolverlaters - voor wie een gezinsleven waarschijnlijk (nog) niet aan de orde is -, kan het wel zo zijn dat de arbeidsmarktkeuzes van jonge vrouwen en hun werkgevers worden gemaakt in anticipatie op een mogelijk latere combinatie van werk en gezinsleven.

In de derde plaats is het soort beroep van schoolverlaters van belang. Differentiatie vindt hier plaats op grond van arbeidsverhoudingen. Beroepen gebaseerd op een dienstverleningsrelatie beschermen tegen marktrisico's, terwijl beroepen op contractbasis de bezetters ervan blootstellen aan arbeidsmarktfluctuaties (Breen, 1997; Goldthorpe, 2000). Het betere arbeidsmarktperspectief voor schoolverlaters in beroepen met een dienstverleningsrelatie (met name professionals en managers) is gerelateerd aan het idee dat deze beroepen gebaseerd zijn op vertrouwen - omdat de taken van werknemers in deze beroepen niet gemakkelijk kunnen worden gecontroleerd - en werkgevers om die reden bereid zijn deze werknemers meer baanzekerheid en betere arbeidsvoorwaarden te bieden om hen aan zich te binden.

In de vierde plaats beïnvloeden bedrijfskenmerken de arbeidsmarktkansen van schoolverlaters. De basis hiervoor is terug te vinden in theorieën over arbeidsmarktsegmentatie (zie bijv. Doeringer \& Piore, 1971), waarin wordt benadrukt dat de arbeidsmarkt niet als een entiteit kan worden beschouwd, maar moet worden onderscheiden in aparte sectoren (primair versus secundair segment, interne arbeidsmarkt versus vakdeelmarkt, enz.) met uiteenlopende arbeidsvoorwaarden en carrièrevooruitzichten. Bedrijfssector en bedrijfsgrootte zijn relevante kenmerken in dit opzicht. Zo wordt verondersteld dat het promotieperspectief voor schoolverlaters gunstiger is in grote bedrijven dan in kleine.

\section{Onderzoeksopzet}

De empirische analyse is gebaseerd op gegevens van het OSA Arbeidsaanbodpanel. Deze panelstudie met gedetailleerde informatie over (veranderingen in) de arbeidsmarktpositie van de (potentiële) beroepsbevolking in Nederland is gestart in 1985, met herhaalde metingen die om het jaar plaatsvinden sinds 1986. Op het eerste meetmoment zijn ongeveer 4.000 respondenten uit een representatieve steekproef van ongeveer 2.100 huishoudens ondervraagd. De doelpopulatie bestaat uit huishoudleden in de leeftijd van 16-64 jaar die geen dagonderwijs volgen. Wanneer panelleden uit de eerste meting in latere metingen niet meer mee konden of wilden doen, zijn zij vervangen door nieuw geselecteerde panelleden en/of huishoudens, die zo veel mogelijk overeenkomen met de oorspronkelijke deelnemers op kenmerken zoals leeftijd, geslacht, gezinsomvang en woonregio. Voor de huidige analyse maak ik gebruik van de gegevens verkregen in de metingen gehouden in de periode 19882002.

Schoolverlaters zijn gedefinieerd als degenen die zich twee jaar voor een bepaald moment van ondervraging in het dagonderwijs bevonden en die dit niet (meer) waren op dat moment van ondervraging (met andere woorden jaar $\mathrm{t}$ en jaar $\mathrm{t}-2$ worden telkens met elkaar vergeleken). Personen die bij het verlaten van het onderwijs minimaal dertig jaar oud waren, zijn uit de data verwijderd. Hetzelfde geldt voor degenen die dienstplichtig militair waren direct na het verlaten van het onderwijs. ${ }^{4}$ Op basis van deze selecties is een analytische steekproef overgebleven van 1.008 respondenten, die het onderwijs in de periode 1986-2002 hebben verlaten. Kenmerken van de arbeidsmarktintrede zijn gemeten op het moment van het eerste interview na het verlaten van het onderwijs (jaar $\mathrm{t}$ ). De volgende twee kenmerken van de arbeidsmarktintrede zijn geanalyseerd: de kans op werkloosheid en de kans op een 
tijdelijke aanstelling. Schoolverlaters zonder werk, maar die daarnaar actief op zoek waren, worden als werkloos beschouwd. Voor werkzame schoolverlaters is vervolgens vastgesteld of zij al dan niet een tijdelijke aanstelling hadden. Een tijdelijke aanstelling met uitzicht op vast is gerekend tot een vaste aanstelling. Daarnaast zijn zelfstandigen (bijv. freelancers) verwijderd uit de gegevens. Beide kenmerken van de arbeidsmarktintrede zijn geanalyseerd met behulp van logit-modellen.

De vroege beroepsloopbaan is gebaseerd op (veranderingen in) de arbeidsmarktpositie in de drie volgende meetmomenten (jaar $t+2$, jaar $t+4$ en jaar $t+6$ ). Met andere woorden: schoolverlaters zijn de eerste zes jaar na het verlaten van het onderwijs gevolgd. In de eerste plaats is de kans op baanverlies bestudeerd. Werklozen zijn individuen zonder werk, maar actief op zoek naar werk. In de tweede plaats is het promotieperspectief van schoolverlaters onderzocht aan de hand van beroepsmobiliteit. Opwaartse en neerwaartse beroepsmobiliteit is gemeten in termen van verandering in beroepsstatus aan de hand van de International Socio-Economic Index (ISEI) van Ganzeboom et al. (1992). Een toename van $10 \%$ of meer van de statusscore is aangemerkt als opwaartse beroepsmobiliteit. Een afname van $10 \%$ of meer als neerwaartse beroepsmobiliteit. Discrete-time transition rate-modellen zijn toegepast om de vroege beroepsloopbaan te analyseren. De risk set beperkt zich tot individuen die werk hebben gevonden na het verlaten van het onderwijs. Werkenden die geen baanverlies hebben meegemaakt noch opwaarts dan wel neerwaarts mobiel zijn geweest, zijn right censored waargenomen. Herhaalde gebeurtenissen zijn mogelijk als het gaat om beroepsmobiliteit.

Verschillende onafhankelijke variabelen zijn in de analyse opgenomen. Het jaar van het verlaten van het onderwijs heeft betrekking op het moment van beëindiging van het dagonderwijs. De afzonderlijke jaren zijn samengevoegd tot vier categorieën: 1986-1988, 19891992, 1993-1996 en 1997-2002. ${ }^{5}$ De tijd verstreken sinds het verlaten van het onderwijs verwijst naar de periode tussen het moment van het verlaten van het dagonderwijs en het moment van ondervraging (uitgedrukt in aantal maanden). De volgende categorieën zijn onderscheiden: 0-3 maanden, 4-6 maanden, 7-12 maanden, 13-24 maanden, 25-48 maanden en 49-72 maanden. Sekseverschillen zijn vastgesteld door een onderscheid tussen mannen en vrouwen te maken. Opleiding is gemeten aan de hand van het hoogst bereikte opleidingsniveau in zes categorieën: basisonderwijs, vbo/mavo, mbo, havo/vwo, hbo en wo. Beroepsklasse is gebaseerd op de EGP sociale klassenindeling (Erikson et al., 1979), bestaande uit zeven categorieën: hogere professionals en managers (klasse I), lagere professionals en managers (klasse II), hogere routinehoofdarbeiders (klasse IIIa), lagere routinehoofdarbeiders (klasse IIIb), kleine zelfstandigen, inclusief zelfstandige boeren (klasse IVabc), geschoolde handarbeiders (klasse V-VI) en semi- en ongeschoolde handarbeiders (klasse VIIab). ${ }^{6}$ Bedrijfssector is vastgesteld aan de hand van een indeling van bedrijfstakken in zeven industry types, ontwikkeld door Stinchcombe (1979) en later ingevuld voor de Nederlandse situatie door Glebbeek (1993). De naamgeving van de sectoren is als volgt: 1) traditionele primaire sector, 2) klassieke kapitalistische industrie, 3) geschoolde concurrerende industrie, 4) grootschalige gebureaucratiseerde industrie, 5) kleinschalige handel en dienstverlening, 6) professionele diensten en 7) bureaucratische diensten. Daarnaast is een restcategorie onderscheiden. Bedrijfsgrootte verwijst naar het aantal werknemers in de vestiging van het bedrijf (1-19 werknemers, 20-199 werknemers, 200-1.999 werknemers, 2.000 en meer werknemers).

Structurele arbeidsmarktomstandigheden verwijzen naar het bestaan van een cohort- en periode-effect (Blossfeld, 1986). In eerste instantie is het cohorteffect afgedekt door het jaar van het verlaten van het onderwijs. Vervolgens is nagegaan in hoeverre de geobserveerde verschillen tussen cohorten kunnen worden toegeschreven aan macro-economische ont- 
wikkelingen. Deze ontwikkelingen zijn geoperationaliseerd als het werkloosheidspercentage in het jaar van het verlaten van het onderwijs. Bij de analyse van de vroege beroepsloopbaan is het periode-effect vastgesteld aan de hand van het huidige werkloosheidspercentage. De werkloosheidspercentages zijn gebaseerd op cijfers over de werkloze beroepsbevolking van het Centraal Bureau voor de Statistiek (CBS, 2006).

Om de invloed van flexibele arbeid op de vroege beroepsloopbaan te bepalen wordt de eerder beschreven variabele die betrekking heeft op het al dan niet werkzaam zijn in een tijdelijke aanstelling, als onafhankelijke variabele aan de analyse toegevoegd. Deze verwijst hier naar de huidige arbeidsmarktpositie.

Bij de analyse van de vroege beroepsloopbaan zijn de meeste variabelen tijdsvariërend gemeten. Alleen het jaar van het verlaten van het onderwijs, het werkloosheidspercentage in het jaar van het verlaten van het onderwijs en sekse zijn tijdsonafhankelijke kenmerken.

\section{Resultaten}

\section{Arbeidsmarktintrede}

Tabel 1 presenteert de resultaten van logit-modellen waarin de kans op werkloosheid bij arbeidsmarktintrede de afhankelijke variabele is. Model 1 laat zien dat de kans op werkloosheid voor schoolverlaters aanzienlijk verschilt in de onderzochte periode. Jongeren die het onderwijs in de periode 1986-1988 zijn uitgestroomd, hebben de grootste werkloosheidskans, gevolgd door degenen die tussen 1993 en 1996 het onderwijs hebben verlaten. Daarentegen hebben schoolverlaters van het cohort 1997-2002 de arbeidsmarkt onder een gunstig gesternte betreden: zij lopen het kleinste risico op werkloosheid. Degenen die het onderwijs in de periode 1989-1992 hebben verlaten, nemen een middenpositie in.

In model 2 zijn de variabelen 'tijd verstreken sinds het verlaten van het onderwijs', 'sekse' en 'opleidingsniveau' toegevoegd. De tijd verstreken sinds het verlaten van het onderwijs heeft een negatieve invloed op de kans op werkloosheid. Jongeren die het onderwijs zeer recent zijn uitgestroomd (0-3 maanden), hebben een grotere kans op werkloosheid dan degenen die langer dan een jaar geleden het onderwijs hebben verlaten (13-24 maanden). De geschatte odds ratio is ongeveer $50 \%$ kleiner in het laatste geval $\left(\mathrm{e}^{-0,75}=0,47\right)$. Verder speelt het bereikte opleidingsniveau een rol bij het risico op werkloosheid. Schoolverlaters met een diploma op het niveau van het mbo zijn het minst werkloos, terwijl afgestudeerden van het hoger onderwijs relatief vaak werkloos zijn na het verlaten van het hbo of de universiteit. Deze bevindingen bevestigen eerder onderzoek (ROA, 2002). Ze verwijzen naar de sterkere oriëntatie op beroepsgerichte vaardigheden in het mbo. Verder geven deze bevindingen aan dat het reserveringsloon van afgestudeerden hoger is. Hoger opgeleiden blijven liever langer werkloos dan dat zij snel een baan onder hun niveau (en tegen een lagere beloning) accepteren. $\mathrm{Zij}$ kunnen zich dit veroorloven, omdat ze relatief vaak van hoge komaf zijn en daardoor financiële steun van hun ouders kunnen verwachten om in hun levensonderhoud te voorzien.

De uiteenlopende kans op werkloosheid voor schoolverlaters in de periode 1986-2002 volgt precies het algemene werkloosheidspatroon in Nederland voor deze periode (zie model 3). Wanneer de cohortdummy's worden vervangen voor het geaggregeerde werkloosheidscijfer in de verschillende jaren, verslechtert de goedpassendheid van het model niet. Dit betekent dat alleen macro-economische ontwikkelingen van belang zijn als het gaat om het verklaren van verschillen in het werkgelegenheidsperspectief voor schoolverlaters in de onderzochte periode. 
Tabel I De kans op werkloosheid bij arbeidsmarktintrede (logit-effecten)

\begin{tabular}{|c|c|c|c|}
\hline & Model I & Model 2 & Model 3 \\
\hline Intercept & $-2,82^{* *}$ & $-2,90 * *$ & $-4,43 * *$ \\
\hline \multicolumn{4}{|l|}{ Jaar van verlaten onderwijs } \\
\hline $1986-1988$ & $1,36^{* * *}$ & $1,48 * *$ & \\
\hline $1989-1992$ & $0,84^{*}$ & $0,96 * *$ & \\
\hline $1993-1996$ & $1,09 * *$ & $1,18^{* * *}$ & \\
\hline $1997-2002$ & ref. & ref. & \\
\hline \multicolumn{2}{|c|}{ Werkloosheid in jaar van verlaten onderwijs } & & $0,35^{* *}$ \\
\hline \multicolumn{4}{|c|}{ Tijd verstreken sinds verlaten onderwijs } \\
\hline $0-3$ maanden & & ref. & ref. \\
\hline 4-6 maanden & & $-0,30$ & $-0,30$ \\
\hline 7-12 maanden & & $-0,42$ & $-0,46+$ \\
\hline 13-24 maanden & & $-0,75 * *$ & $-0,80 * *$ \\
\hline \multicolumn{4}{|l|}{ Sekse } \\
\hline Man & & ref. & ref. \\
\hline Vrouw & & $-0,26$ & $-0,28$ \\
\hline \multicolumn{4}{|l|}{ Opleidingsniveau } \\
\hline Basisonderwijs & & 0,59 & 0,63 \\
\hline Mavo/vbo & & 0,33 & 0,35 \\
\hline Mbo & & ref. & ref. \\
\hline Havo/vwo & & 0,49 & 0,53 \\
\hline Hbo & & $0,92 * *$ & $0,94^{* * *}$ \\
\hline Wo & & $0,89+$ & $0,88+$ \\
\hline Model Chi ${ }^{2}$ & $19,06 * *$ & $43,73 * *$ & $44,34 * *$ \\
\hline Aantal vrijheidsgraden & 3 & 12 & 10 \\
\hline Aantal respondenten & 1008 & 1008 & 1008 \\
\hline
\end{tabular}

** effect significant bij $\mathrm{P}<0,0 \mathrm{I} ; *$ effect significant bij $\mathrm{P}<0,05 ;+$ effect significant bij $\mathrm{P}<0,10$

Bron: OSA Arbeidsaanbodpanel 1988-2002

In tabel 2 zijn de resultaten van de analyse van de kans op een tijdelijke aanstelling weergegeven. Model 1 toont dat de kans op een tijdelijke aanstelling het grootst is voor schoolverlaters die in de periode 1993-1996 zijn uitgestroomd. Voor hen is de kansverhouding op een tijdelijke versus vaste aanstelling twee keer groter als de overeenkomstige kansverhouding voor schoolverlaters van het cohort 1997-2002 $\left(e^{0,69}=2,00\right)$. Daarnaast is gevonden dat de tijd verstreken sinds het verlaten van het onderwijs een negatieve invloed heeft op de kans op een tijdelijke aanstelling. Schoolverlaters die 13-24 maanden geleden zijn uitgestroomd, hebben een kleinere kans op een tijdelijke aanstelling dan degenen die 0-3 maanden geleden het onderwijs hebben verlaten. Ten slotte laat model 1 zien dat de kans op een tijdelijke instelling (in beperkte mate) wordt bepaald door het opleidingsniveau van schoolverlaters. Degenen zonder diploma na het basisonderwijs hebben de grootste kans om de arbeidsmarkt te betreden via een tijdelijke aanstelling.

In model 2 zijn beroeps- en bedrijfskenmerken toegevoegd. Dit model laat in de eerste plaats zien dat schoolverlaters, die in de beroepsklasse van lagere professionals en managers zijn terechtgekomen, het minst een tijdelijke aanstelling hebben. In de tweede plaats is de bedrijfssector van belang bij de kans op een tijdelijke aanstelling bij arbeidsmarktintrede. Schoolverlaters die zich in de restcategorie bevinden, lopen de grootste kans op een tijdelijke aanstelling. Voor een groot deel wordt deze categorie gevormd door de uitzendbranche, waar tijdelijke aanstellingen gewoon zijn. Verder zijn schoolverlaters in de professionele diensten, grootschalige gebureaucratiseerde industrie en de klassieke kapitalistische industrie relatief vaak werkzaam op tijdelijke basis. 
Tabel 2 De kans op een tijdelijke aanstelling bij arbeidsmarktintrede (logit-effecten)

\begin{tabular}{lll}
\hline & Model I & Model \\
\hline Intercept & $-0,64^{* *}$ & $-0,96 * *$ \\
Jaar van verlaten onderwijs & & \\
1986-1988 & $-0,18$ & $-0,17$ \\
$1989-1992$ & $-0,03$ & $-0,04$ \\
$1993-1996$ & $0,69 * *$ & $0,70^{* *}$ \\
$1997-2002$ & ref. & ref.
\end{tabular}

Werkloosheid in jaar van verlaten onderwijs

Model 3

$-1,66$ **

Tijd verstreken sinds verlaten onderwijs

0-3 maanden

ref.

0,14

$-0,37+$

$-0,76 * *$

ref.

$-0,18$

ref.

ref.

0,04

$-0,38+$

$-0,78 * *$

$0,13^{*}$

13-24 maanden

Sekse

Man

Vrouw

$0,61+$

Opleidingsniveau

Mavo/vbo

Mbo

Havo/vwo

Hbo

0,20

ref.

$-0,02$

$-0,19$

$-0,02$

$-0,15$

ref.

$-0,14$

Wo

0,50

0,08

0,51

ref.

0,08

$-0,11$

ref.

0,10

$-0,11$

0,15

0,01

0,16

Beroepsklasse

Hogere professionals en managers

Lagere professionals en managers

Hogere routinehoofdarbeiders

Lagere routinehoofdarbeiders

Geschoolde handarbeiders

Semi- en ongeschoolde handarbeiders

Bedrijfssector

Traditionele primaire sector

Klassieke kapitalistische industrie

Geschoolde concurrerende industrie

Grootschalige gebureaucratiseerde industrie

Kleinschalige handel en dienstverlening

Professionele diensten

Bureaucratische diensten

Overig

\begin{tabular}{lll} 
& $-0,75$ & $-0,76$ \\
& $-0,95^{* *}$ & $-0,89 * *$ \\
& $-0,42$ & $-0,51$ \\
& $-0,06$ & $-0,01$ \\
& ref. & ref. \\
& 0,40 & 0,43 \\
& & \\
& 0,80 & 0,99 \\
& $0,68+$ & $0,70+$ \\
& ref. & ref. \\
& $0,72+$ & $0,71+$ \\
& 0,44 & 0,44 \\
& $0,77^{*}$ & $0,77^{*}$ \\
& $-0,05$ & $-0,05$ \\
& $1,29 * *$ & $1,26 * *$ \\
& & \\
778 & ref. & ref. \\
$48,45^{* *}$ & 0,03 & 0,05 \\
& 0,26 & 0,27 \\
& 0,57 & 0,76 \\
& $85,03^{* *}$ & $70,29 * *$ \\
& 27 & 25 \\
& 778 & 778 \\
\hline
\end{tabular}

Bedrijfsgrootte

I-19 werknemers

20-199 werknemers

200-1.999 werknemers

2.000 en meer werknemers

Model $\mathrm{Chi}^{2}$

Aantal vrijheidsgraden

Aantal respondenten

** effect significant bij $\mathrm{p}<0,01$; * effect significant bij $\mathrm{p}<0,05 ;+$ effect significant bij $\mathrm{p}<0,10$

Bron: OSA Arbeidsaanbodpanel 1988-2002 
Model 3 toont dat het werkloosheidspercentage in het jaar van het verlaten van het onderwijs een positief effect heeft op de kans op een tijdelijke aanstelling. Elke procent stijging in werkloosheid gaat gepaard met een toename in de kansverhouding op een tijdelijke versus vaste aanstelling van $14 \%\left(\mathrm{e}^{0,13}=1,14\right)$. Daarmee steunt deze bevinding de opvatting dat flexibele arbeid wordt ingezet als instrument om jeugdwerkloosheid te bestrijden: in tijden van hoge werkloosheid lopen schoolverlaters een groter risico in een tijdelijke aanstelling terecht te komen dan in tijden van lage werkloosheid.

\section{Vroege beroepsloopbaan}

De tabellen 3 en 4 geven de uitkomsten weer van een reeks discrete duurmodellen waarin de transition rate (de conditionele kans dat een gebeurtenis op een bepaald tijdstip plaatsvindt) van de overgang van werk naar werkloosheid en de overgang van een bepaald beroep naar een hoger of lager beroep in de eerste zes jaar na het verlaten van het onderwijs als afhankelijke variabele fungeert. ${ }^{7}$

Model 1 van tabel 3 toont dat schoolverlaters met een tijdelijke aanstelling eerder hun baan verliezen tijdens de vroege beroepsloopbaan dan degenen met een contract voor onbepaalde tijd. De geschatte odds ratio is $6,30\left(\mathrm{e}^{1,84}\right)$, wat impliceert dat voor schoolverlaters met een tijdelijke aanstelling het relatieve risico om werkloos te zijn op het volgende meetmoment (dat wil zeggen twee jaar later) meer dan zes keer groter is dan voor degenen met een vaste aanstelling. Dit effect is zelfs groter wanneer ook rekening wordt gehouden met de kenmerken 'beroepsklasse', 'bedrijfssector' en 'bedrijfsgrootte' (zie model 2). In dat geval bedraagt de odds ratio $7,54\left(\mathrm{e}^{2,02}\right)$.

Naast het hebben van een tijdelijke aanstelling zijn de tijd die is verstreken sinds het verlaten van het onderwijs, en het bereikte opleidingsniveau van invloed op de conditionale kans om werkloos te worden (zie model 3). Ten eerste hebben schoolverlaters die het onderwijs 13-24 maanden geleden zijn uitgestroomd een grotere kans om hun baan te verliezen dan degenen die het onderwijs maximaal 3 maanden geleden hebben verlaten. Ten tweede lopen afgestudeerden van universiteiten en schoolverlaters van het mbo een groter risico om werkloos te worden dan schoolverlaters van het vbo of mavo.

Tabel 4 laat zien welke factoren van belang zijn bij opwaartse en neerwaartse beroepsmobiliteit. Aan de modellen is het beroepsniveau van de huidige baan als variabele toegevoegd om te corrigeren voor respectievelijk plafond- en bodemeffecten. Met betrekking tot opwaartse mobiliteit tonen de resultaten in de eerste plaats dat de tijd verstreken sinds het verlaten van het onderwijs een invloed heeft (zie model 1). Naarmate meer tijd verstreken is sinds het verlaten van het onderwijs, des te groter is de kans op promotie. In de tweede plaats ondervinden vrouwen vaker opwaartse beroepsmobiliteit in de vroege beroepsloopbaan dan mannen. In de derde plaats zijn de laagst opgeleiden (dat wil zeggen schoolverlaters die maximaal over een diploma op het niveau van het vbo of mavo beschikken) het minst opwaarts mobiel. 
Tabel 3 De kans op baanverlies tijdens de vroege beroepsloopbaan (logit-effecten)

\begin{tabular}{|c|c|c|c|}
\hline & Model I & Model 2 & Model 3 \\
\hline Intercept & $-4,18 * *$ & $-4,2 I^{* *}$ & $-6,02^{*}$ \\
\hline \multicolumn{4}{|l|}{ Tijdelijke aanstelling } \\
\hline Nee & ref. & ref. & ref. \\
\hline $\mathrm{Ja}$ & $1,84 * *$ & $2,02 * *$ & $1,98 * *$ \\
\hline \multicolumn{4}{|l|}{ Jaar van verlaten onderwijs } \\
\hline $1986-1988$ & 0,88 & 1,07 & \\
\hline 1989-1992 & 0,44 & 0,47 & \\
\hline $1993-1996$ & 0,27 & 0,57 & \\
\hline $1997-2000$ & ref. & ref. & \\
\hline Werkloosheid in jaar van verlaten onderwijs & & & 0,34 \\
\hline Huidige werkloosheid & & & $-0,02$ \\
\hline \multicolumn{4}{|l|}{ Tijd verstreken sinds verlaten onderwijs } \\
\hline $0-3$ maanden & ref. & ref. & ref. \\
\hline 4-6 maanden & $-0,18$ & $-0,39$ & $-0,44$ \\
\hline $7-12$ maanden & $-0,65$ & $-0,87$ & $-0,88$ \\
\hline 13-24 maanden & $-2,09+$ & $-2,18+$ & $-2,26^{*}$ \\
\hline 25-48 maanden & $-0,57$ & $-0,54$ & $-0,58$ \\
\hline 49-72 maanden & $-1,34$ & $-1,46$ & $-1,50$ \\
\hline \multicolumn{4}{|l|}{ Sekse } \\
\hline Man & ref. & ref. & ref. \\
\hline Vrouw & 0,17 & 0,60 & 0,52 \\
\hline \multicolumn{4}{|l|}{ Opleidingsniveau } \\
\hline Basisonderwijs & - & - & - \\
\hline Mavo/vbo & $-0,30$ & $-0,12$ & $-0,06$ \\
\hline Mbo & ref. & ref. & ref. \\
\hline Havo/vwo & 1,08 & 1,27 & $|, 4|+$ \\
\hline Hbo & $-0,94$ & $-\mid, 0 I$ & $-0,98$ \\
\hline Wo & 1,35 & $2,47^{*}$ & $2,52^{*}$ \\
\hline \multicolumn{4}{|l|}{ Beroepsklasse } \\
\hline Hogere professionals en managers & & - & - \\
\hline Lagere professionals en managers & & 0,22 & 0,25 \\
\hline Hogere routinehoofdarbeiders & & $-0,13$ & $-0,04$ \\
\hline Lagere routinehoofdarbeiders & & 0,20 & 0,26 \\
\hline Geschoolde handarbeiders & & ref. & ref. \\
\hline Semi- en ongeschoolde handarbeiders & & 0,89 & 0,86 \\
\hline \multicolumn{4}{|l|}{ Bedriifssector } \\
\hline Traditionele primaire sector & & - & - \\
\hline Klassieke kapitalistische industrie & & - & - \\
\hline Geschoolde concurrerende industrie & & ref. & ref. \\
\hline Grootschalige gebureaucratiseerde industrie & & $-I, 54$ & $-\mid, 6 I$ \\
\hline Kleinschalige handel en dienstverlening & & $-0,46$ & $-0,40$ \\
\hline Professionele diensten & & $-0,94$ & $-0,96$ \\
\hline Bureaucratische diensten & & $-0,82$ & $-0,78$ \\
\hline Overig & & 0,16 & 0,29 \\
\hline \multicolumn{4}{|l|}{ Bedrijfsgrootte } \\
\hline $1-19$ werknemers & & ref. & ref. \\
\hline 20-199 werknemers & & $-0,83$ & $-0,85$ \\
\hline 200-I.999 werknemers & & 0,63 & 0,68 \\
\hline 2.000 en meer werknemers & & - & - \\
\hline
\end{tabular}


Tabel 3 (vervolg)

\begin{tabular}{|c|c|c|c|}
\hline & Model I & Model 2 & Model 3 \\
\hline Model Chi ${ }^{2}$ & $29,48^{*}$ & $45,60 *$ & $45,7 \mid *$ \\
\hline Aantal vrijheidsgraden & 15 & 30 & 29 \\
\hline Aantal gebeurtenissen & 18 & 18 & 18 \\
\hline Aantal sub-episodes & 634 & 634 & 634 \\
\hline
\end{tabular}

** effect significant bij $\mathrm{P}<0,0 \mathrm{I}$; * effect significant bij $\mathrm{P}<0,05 ;+$ effect significant bij $\mathrm{P}<0, \mathrm{I} 0$

- = coëfficiënt niet betrouwbaar vanwege gering aantal waarnemingen en daarom niet weergegeven

Bron: OSA Arbeidsaanbodpanel 1988-2002

Model 2 geeft aan dat het oorspronkelijke sekseverschil in de kans op opwaartse beroepsmobiliteit verdwijnt zodra rekening wordt gehouden met de invloed van beroeps- en bedrijfskenmerken. Dit duidt erop dat de relatief grotere kans op opwaartse mobiliteit voor vrouwen voortkomt uit het feit dat zij vaker dan mannen werkzaam zijn in beroepen en bedrijven waar opwaartse beroepswisselingen veel voorkomen. Vooral in de beroepsklasse van professionals en managers en in de klasse van routinehoofdarbeiders is de waarschijnlijkheid van opwaartse mobiliteit groter dan in de klasse van geschoolde handarbeiders. Daarnaast hebben schoolverlaters die werken in de professionele diensten een geringere kans op opwaartse mobiliteit dan degenen die werkzaam zijn in de geschoolde concurrerende industrie. Tot slot zijn jonge werknemers in zeer grote bedrijven (2.000 of meer werknemers) vaker opwaarts mobiel. Deze bevinding houdt vast en zeker verband met de interne arbeidsmarktstructuur van grote bedrijven, waar een aan werkervaring gerelateerd patroon van opwaartse mobiliteit kan worden gevonden.

In model 3 wordt aangetoond dat structurele arbeidsmarktomstandigheden promotiekansen tijdens de vroege beroepsloopbaan beïnvloeden. Het negatieve effect van het huidige werkloosheidspeil op de waarschijnlijkheid van opwaartse mobiliteit geeft aan dat de kans op opwaartse beroepsmobiliteit geringer is in tijden van laagconjunctuur.

Ook met betrekking tot neerwaartse mobiliteit doet de tijd die is verstreken sinds het verlaten van het onderwijs ertoe, ook al is het geschatte effect hier niet lineair. Model 1 laat zien dat schoolverlaters die 4-6 maanden geleden zijn uitgestroomd, verreweg de grootste kans hebben op neerwaartse beroepswisselingen. De geschatte odds ratio bedraagt 6,17 $\left(\mathrm{e}^{1,82}\right)$. Dit zegt iets over het instabiele karakter van de (zeer) vroege beroepsloopbaan. Daarnaast laat model 1 zien dat opleiding beschermt tegen neerwaartse mobiliteit. Niet alleen afgestudeerden van het hoger onderwijs, maar ook schoolverlaters van het havo/vwo en het vbo/mavo ondervinden minder snel een daling in beroepsniveau dan schoolverlaters van het mbo.

Model 2 geeft aan dat beroeps- en bedrijfskenmerken nauwelijks van belang zijn bij neerwaartse beroepsmobiliteit. Alleen schoolverlaters die in de restcategorie van de variabele bedrijfssector vallen (nogmaals: deze categorie heeft hoofdzakelijk betrekking op de uitzendbranche), lopen een groter risico op neerwaartse mobiliteit.

In model 3 wordt wederom aangetoond dat structurele arbeidsmarktomstandigheden van invloed zijn op beroepsmobiliteit. Het huidige werkloosheidspercentage heeft een positief effect op de waarschijnlijkheid van neerwaartse mobiliteit. In tijden van hoge werkloosheid is de kans op neerwaartse beroepswisselingen groter dan in tijden van lage werkloosheid. 
Tabel 4 De kans op opwaartse en neerwaartse beroepsmobiliteit tijdens de vroege beroepsloopbaan (logit-effecten)

\begin{tabular}{|c|c|c|c|c|c|c|}
\hline & \multicolumn{3}{|c|}{ Opwaarts } & \multicolumn{3}{|c|}{ Neerwaarts } \\
\hline & Model I & Model 2 & Model 3 & Model I & Model 2 & Model 3 \\
\hline Intercept & 0,78 & 1,20 & $2,35+$ & $-3,20 * *$ & $-2,8 I^{* *}$ & $-3,68^{*}$ \\
\hline Beroepsniveau & $-0,07^{* *}$ & $-0,13^{* *}$ & $-0,13^{* *}$ & $0,05 * *$ & $0,04+$ & $0,04^{*}$ \\
\hline \multicolumn{7}{|l|}{ Tijdelijke aanstelling } \\
\hline Nee & ref. & ref. & ref. & ref. & ref. & ref. \\
\hline Ja & 0,18 & 0,14 & 0,25 & $-0,17$ & $-0,11$ & $-0,16$ \\
\hline \multicolumn{7}{|l|}{ Jaar van verlaten onderwijs } \\
\hline $1986-1988$ & $-0,22$ & 0,07 & & $-0,72$ & $-0,76$ & \\
\hline $1989-1992$ & 0,30 & 0,68 & & $-0,40$ & $-0,40$ & \\
\hline $1993-1996$ & 0,24 & 0,67 & & 0,14 & 0,14 & \\
\hline $1997-2000$ & ref. & ref. & & ref. & ref. & \\
\hline Werkloosheid in jaar van verlaten onderwijs & & & 0,14 & & & $-0,19$ \\
\hline Huidige werkloosheid & & & $-0,20+$ & & & $0,25^{*}$ \\
\hline \multicolumn{7}{|l|}{ Tijd verstreken sinds verlaten onderwijs } \\
\hline 0-3 maanden & ref. & ref. & ref. & ref. & ref. & ref. \\
\hline 4-6 maanden & 0,03 & $-0,05$ & $-0,01$ & $1,82 * *$ & $1,91 *$ & I,73* \\
\hline $7-12$ maanden & $0,76+$ & 0,69 & 0,62 & 0,55 & 0,34 & 0,38 \\
\hline 13-24 maanden & 0,45 & 0,47 & 0,44 & $0,69+$ & $0,77+$ & $0,70+$ \\
\hline 25-48 maanden & $0,76^{*}$ & $0,94 *$ & $0,79 *$ & 0,13 & 0,20 & 0,16 \\
\hline 49-72 maanden & $1,08 * *$ & $1,12 *$ & $0,96 *$ & 0,73 & $0,83+$ & 0,70 \\
\hline \multicolumn{7}{|l|}{ Sekse } \\
\hline Man & ref. & ref. & ref. & ref. & ref. & ref. \\
\hline Vrouw & $0,57^{*}$ & 0,28 & 0,18 & 0,00 & 0,08 & 0,16 \\
\hline \multicolumn{7}{|l|}{ Opleidingsniveau } \\
\hline Basisonderwijs & $-1,23+$ & $-1,10$ & $-1,02$ & $-0,37$ & $-0,65$ & $-0,58$ \\
\hline Mavo/vbo & $-1,02 * *$ & $-0,85^{* *}$ & $-0,78^{*}$ & $-0,91 * *$ & $-0,97 * *$ & $-0,99 * *$ \\
\hline Mbo & ref. & ref. & ref. & ref. & ref. & ref. \\
\hline Havo/vwo & $-0,02$ & 0,12 & 0,32 & $-1,11+$ & $-0,82$ & $-0,95$ \\
\hline Hbo & 0,02 & 0,37 & 0,28 & $-1,4 I^{* *}$ & $-1,26 * *$ & $-1,23 * *$ \\
\hline Wo & 0,56 & 0,83 & 0,94 & $-2,12^{* * *}$ & $-1,97^{*}$ & $-2,17^{* *}$ \\
\hline \multicolumn{7}{|l|}{ Beroepsklasse } \\
\hline Hogere professionals en managers & & $2,46 * *$ & $2,82^{* *}$ & & 0,27 & 0,21 \\
\hline Lagere professionals en managers & & $2,64 * *$ & $2,76 * *$ & & 0,30 & 0,17 \\
\hline Hogere routinehoofdarbeiders & & $2,66 * *$ & $2,68 * *$ & & 0,14 & $-0,10$ \\
\hline Lagere routinehoofdarbeiders & & $2,01 * *$ & $2,05 * *$ & & $-0,40$ & $-0,44$ \\
\hline Geschoolde handarbeiders & & ref. & ref. & & ref. & ref. \\
\hline Semi- en ongeschoolde handarbeiders & & 0,65 & 0,61 & & $-0,32$ & $-0,21$ \\
\hline \multicolumn{7}{|l|}{ Bedrijfssector } \\
\hline Traditionele primaire sector & & $-0,59$ & $-0,49$ & & - & - \\
\hline Klassieke kapitalistische industrie & & 0,50 & 0,47 & & 0,04 & $-0,04$ \\
\hline Geschoolde concurrerende industrie & & ref. & ref. & & ref. & ref. \\
\hline Grootschalige gebureaucratiseerde industrie & & 0,12 & $-0,08$ & & $-0,13$ & $-0,24$ \\
\hline Kleinschalige handel en dienstverlening & & 0,34 & 0,22 & & 0,43 & 0,40 \\
\hline Professionele diensten & & $-1,24^{*}$ & $-1,40 * *$ & & $-0,66$ & $-0,62$ \\
\hline Bureaucratische diensten & & 0,56 & 0,57 & & 0,67 & 0,50 \\
\hline Overig & & $1,45+$ & 1,22 & & $2,17+$ & $2,32 *$ \\
\hline \multicolumn{7}{|l|}{ Bedrijfsgrootte } \\
\hline $1-19$ werknemers & & ref. & ref. & & ref. & ref. \\
\hline 20-199 werknemers & & $-0,00$ & 0,02 & & $-0,27$ & $-0,23$ \\
\hline 200-I.999 werknemers & & $-0,24$ & $-0,27$ & & $-0,38$ & $-0,36$ \\
\hline 2.000 en meer werknemers & & $2,02 *$ & $1,96 *$ & & 0,81 & 1,31 \\
\hline
\end{tabular}


Tabel 4 (vervolg)

\begin{tabular}{lllllll}
\hline & \multicolumn{2}{c}{ Opwaarts } & \multicolumn{2}{c}{ Neerwaarts } \\
& Model I & Model 2 & Model 3 & Model I & Model 2 & Model 3 \\
\hline Model Chi ${ }^{2}$ & $60,32^{* *}$ & $108,82^{* *}$ & $107,26 * *$ & $47,03 * *$ & $66,43^{* *}$ & $64,72^{* *}$ \\
Aantal vrijheidsgraden & 16 & 31 & 30 & 16 & 30 & 29 \\
Aantal gebeurtenissen & 114 & 114 & 114 & 87 & 87 & 87 \\
Aantal sub-episodes & 517 & 517 & 517 & 482 & 482 & 482 \\
\hline
\end{tabular}

** effect significant bij $\mathrm{p}<0,0 \mathrm{I}$; * effect significant bij $\mathrm{p}<0,05 ;+$ effect significant bij $\mathrm{p}<0,10$

- = coëfficiënt niet betrouwbaar vanwege gering aantal waarnemingen en daarom niet weergegeven

Bron: OSA Arbeidsaanbodpanel 1988-2002

\section{Conclusies}

In dit artikel zijn de gevolgen van arbeidsmarktflexibilisering in Nederland onderzocht voor jongeren die sinds het midden van de jaren tachtig van de vorige eeuw voor het eerst de arbeidsmarkt hebben betreden. De nadruk lag op schoolverlaters, omdat vooral zij met flexibele arbeid worden geconfronteerd in de strijd om beschikbare banen met zittende werknemers. De arbeidsmarktintrede is bepaald aan de hand van de kans op werkloosheid en de kans op een tijdelijke aanstelling. De vroege beroepsloopbaan is vastgesteld in termen van baanverlies en beroepsmobiliteit. Het OSA Arbeidsaanbodpanel is gebruikt voor de empirische analyse.

Ten aanzien van de arbeidsmarktintrede hebben de resultaten laten zien dat het werkgelegenheidsperspectief voor schoolverlaters in Nederland aanzienlijk is verbeterd in de periode 1986-2002. De sterk gedaalde kans op werkloosheid voor schoolverlaters is volledig toe te schrijven aan de over het algemeen verbeterde macro-economische ontwikkelingen op de Nederlandse arbeidsmarkt in die periode. Afgestudeerden van het hbo en het wo hebben een grotere kans op werkloosheid bij arbeidsmarktintrede dan schoolverlaters van het mbo. Dit resultaat geeft aan dat de nadruk op het aanleren van beroepsgerichte vaardigheden meer centraal staat in het mbo dan in het hoger onderwijs. Bovendien laat het zien dat het reserveringsloon voor tertiair opgeleiden hoger is. Het verbeterde werkgelegenheidsperspectief voor schoolverlaters bij arbeidsmarktintrede is echter samengegaan met een vergroot risico op een tijdelijke aanstelling. Daarmee wordt bevestigd dat flexibele arbeid een geslaagd middel is geweest om de destijds hoge jeugdwerkloosheid in Nederland aan te pakken. Met name jongeren die in de periode 1993-1996 het onderwijs hebben verlaten, worden geconfronteerd met een tijdelijke aanstelling bij arbeidsmarktintrede. De kans op flexibele arbeid loopt wel uiteen voor verschillende sociale groepen. Uit de bevindingen is naar voren gekomen dat de laagst opgeleide schoolverlaters de grootste kans hebben op een tijdelijke aanstelling. Schoolverlaters die de beroepsklasse van lagere professionals en managers hebben betreden, zijn daarentegen het minst in een tijdelijke aanstelling te vinden.

Ten aanzien van de vroege beroepsloopbaan hebben de uitkomsten uitgewezen dat schoolverlaters met een tijdelijke aanstelling vaker hun baan verliezen dan schoolverlaters met een vaste aanstelling. Deze bevinding suggereert dat flexibele arbeid eerder als een valstrik kan worden beschouwd - waarbij periodes van werk en werkloosheid elkaar afwisselen - dan als een opstap naar een stabiele arbeidsmarktpositie.

Flexibele arbeid heeft echter geen invloed op opwaartse en neerwaartse beroepsmobiliteit tijdens de vroege loopbaan. Het zijn vooral individuele kenmerken van schoolverlaters die bepalend zijn bij de kans op beroepsmobiliteit. Wat betreft opwaartse mobiliteit is allereerst gevonden dat de laagst opgeleide schoolverlaters het minst opwaartse beroepswisselingen meemaken. Daarnaast is de kans op opwaartse mobiliteit het grootst voor schoolverlaters die werkzaam zijn in de beroepsklasse van professionals en managers en in de klasse van 
routinehoofdarbeiders. Verder hebben schoolverlaters die werken in zeer grote bedrijven een grotere kans op promotie; ongetwijfeld als gevolg van de aanwezige interne arbeidsmarktstructuur daar. Wat betreft neerwaartse mobiliteit is gevonden dat met name opleiding beschermt tegen neerwaartse beroepswisselingen. In het bijzonder hebben afgestudeerden van het hoger onderwijs een kleinere kans op neerwaartse mobiliteit, gevolgd door schoolverlaters van het voortgezet onderwijs. Ten slotte hebben de resultaten uitgewezen dat structurele arbeidsmarktomstandigheden van invloed zijn op beroepsmobiliteit. In tijden van hoge werkloosheid vinden opwaartse beroepwisselingen minder en neerwaartse beroepswisselingen meer plaats dan in tijden van lage werkloosheid.

Als het gaat om de gevolgen van arbeidsmarktflexibilisering voor de kans om werkloos te worden, dan komen de hier gedane bevindingen overeen met de resultaten van eerder onderzoek van Steijn et al. (2006). In beide gevallen wordt geconstateerd dat een tijdelijke aanstelling bij aanvang op de arbeidsmarkt leidt tot een grotere kans op (latere) werkloosheid. Wat betreft de gevolgen van een tijdelijke aanstelling voor de beroepsloopbaankansen van individuen is er geen gelijkenis. Steijn et al. (2006) vonden een positief effect van een tijdelijke aanstelling bij arbeidsmarktintrede op opwaartse beroepsmobiliteit, terwijl een dergelijk effect hier niet is geconstateerd. Dit laatste resultaat is echter wel in overeenstemming met de bevindingen van Steijn (1999), die - alhoewel zijn analyse betrekking had op de totale beroepsbevolking - concludeert dat de initiële achterstand in functieniveau van flexibele werknemers niet wordt ingehaald. Het verschil in gevonden resultaten heeft wellicht te maken met de gebruikte gegevens. Zowel in dit artikel als in Steijn (1999) is gebruikgemaakt van prospectieve paneldata van de OSA, terwijl Steijn et al. (2006) retrospectieve levensloopgegevens uit de Familie-enquête Nederlandse Bevolking 2000 analyseerden. De laatstgenoemde data bestrijken een veel langere periode van de levensloop van individuen, waardoor het inhaaleffect zich daar wel openbaart. Verder onderzoek moet uitwijzen of de onderzochte termijn inderdaad bepalend is voor het optreden van het inhaaleffect. Het is daarbij tevens interessant om na te gaan of ook andere kenmerken van een slechte start op de arbeidsmarkt van tijdelijke aard zijn (zoals bijvoorbeeld de wachtkamerhypothese stelt in het geval van overscholing), dan wel blijvende, nadelige gevolgen hebben voor de latere beroepsloopbaan van individuen.

\section{Noten}

1 Merk op dat de term werkzekerheid wordt gebruikt in plaats van baanzekerheid, verwijzend naar de neergang van de standaard vaste baan voor het leven.

2 Desondanks is deeltijdarbeid onder jongeren (in de leeftijd van 15-24 jaar) flink gestegen in Nederland. Deze stijging is echter grotendeels veroorzaakt door de toegenomen arbeidsmarktdeelname van scholieren en studenten (Van der Meer \& Wielers, 2001). Tegenwoordig hebben veel jongeren tijdens de zomerperiode als tijdens het school- of studiejaar een bijbaan. Er zijn twee belangrijke redenen voor de toegenomen arbeidsmarktparticipatie van scholieren en studenten. Een eerste reden betreft de bezuinigingen op de studiefinanciering. Deze beleidsmaatregel heeft ertoe geleid dat veel jongeren een bijbaan zijn gaan nemen om zo hun studie te bekostigen en in het levensonderhoud te kunnen voorzien. Een tweede reden heeft direct betrekking op de flexibilisering van de arbeidsmarkt. Jongeren zijn flexibel, omdat zij naast hun studie vaak geen andere verplichtingen (zoals de zorg voor een gezin) hebben en op onregelmatige tijden (zoals's avonds) kunnen werken. Dit maakt hen uiterst aantrekkelijk voor werkgevers die tijdelijk werk en deeltijdwerk aan te bieden hebben.

3 Ook ander Nederlands onderzoek toont dat flexibele arbeid van invloed is op de loopbaankansen van individuen, maar deze studies richten zich op de totale beroepsbevolking in plaats van specifiek op schoolverlaters. Zo laat Steijn (1999) zien dat flexibele werknemers bijna twee keer zo vaak werkloos worden als werknemers met een vast dienstverband. Daarnaast concludeert hij dat de banen die flexibele werknemers hebben van een lager niveau zijn dan die van werknemers met een vast dienstverband. Deze achterstand in functieniveau wordt gedurende de loopbaan niet goedgemaakt. Van een inhaaleffect is er met andere woorden geen sprake. Muffels et al. (1999) bestuderen vooral de vraag of een flexibele baan 
een opstap is naar een vaste baan dan wel een eindstation. Zij vinden dat ongeveer de helft van de werknemers, die in een flexibel dienstverband terechtkomen, binnen 3 à 4 jaar weer een vaste baan hebben. Voor hen is een flexibele baan dus als een opstap naar een stabiele arbeidsmarktpositie te beschouwen. Ook in ander onderzoek (Kleinknecht et al., 1997; Remery et al., 2002) wordt geconstateerd dat voor veel flexwerkers het flexibele contract een opstap betekent naar een vaste baan.

4 Het gaat om een klein aantal mannen, omdat de militaire dienstplicht in 1996 is afgeschaft.

5 Bij de analyse van de vroege beroepsloopbaan verwijst de laatste categorie naar de periode 1997-2000.

6 Omdat zelfstandigen zijn verwijderd uit de gegevens, komt de beroepsklasse IVabc (kleine zelfstandigen, inclusief zelfstandige boeren) niet voor in de resultaten.

7 Selectieve paneluitval verstoort mogelijkerwijs de geschatte regressiecoëfficiënten. Van alle schoolverlaters die participeren op een bepaald meetmoment neemt slechts de helft nog deel op het volgende meetmoment. Deze uitval is hoger dan gemiddeld in het OSA Arbeidsaanbodpanel - door de bank genomen is de uitval ongeveer een derde tussen twee opeenvolgende metingen in dit panel van huishoudens -, met name veroorzaakt door het feit dat jongeren rond de periode van het verlaten van het onderwijs ook het ouderlijk huis (en daarmee het geselecteerde huishouden in het panel) verlaten. Pogingen om hen op te sporen en naderhand te ondervragen zijn helaas niet zo succesvol gebleken. Om die reden heb ik een correctie voor sample selection bias uitgevoerd (Maddala, 1983). Hieruit is gebleken dat de geconstrueerde correctievariabele geen significant effect heeft op de onderzochte afhankelijke variabelen noch dat modellen met en zonder correctie voor selectiebias wezenlijk van elkaar verschillen. Op basis hiervan heb ik besloten om de resultaten van de analyse van de vroege beroepsloopbaan te presenteren aan de hand van de modellen zonder correctie voor selectiebias.

\section{Literatuur}

Blossfeld, H.-P. (1986). Career opportunities in the Federal Republic of Germany: a dynamic approach to the study of life-cycle, cohort, and period effects. European Sociological Review, 2, 208-225.

Blossfeld, H.-P. \& Hakim, C. (1997) (red.). Between equalisation and marginalisation: Women working part-time in Europe and the United States. Oxford: Oxford University Press.

Breen, R. (1997). Risk, recommodification and stratification. Sociology, 31, 473-489.

Breen, R. \& Buchmann, M. (2002). Institutional variation and the position of young people: A comparative perspective. The Annals of the American Academy of Political and Social Science, 580, 288-305.

Castells, M. (2000). The rise of the network society. The information age. Oxford: Blackwell Publishers.

CBS (2006). StatLine databank. Centraal Bureau voor de Statistiek: Voorburg/Heerlen. Online beschikbaar via <statline.cbs.nl> (geraadpleegd op 14 juni 2006).

Córdova, E. (1986). From full-time employment to atypical employment: A major shift in the evolution of labour relations? International Labour Review, 125, 641-657.

De Vreyer, Ph., Layte, R., Wolbers, M.H.J. \& Hussain, M. (2000). The permanent effects of labour market entry in times of high unemployment. In: D. Gallie \& S. Paugam (red.). Welfare regimes and the experience of unemployment in Europe (pp. 134-152). Oxford: Oxford University Press.

DiPrete, T. (2005). Labor markets, inequality and change: A European perspective. Work and Occupations, 32, 119-139.

Doeringer, P. \& Piore, M. (1971). Internal labor markets and manpower analysis. Lexington, MA: Heath.

Erikson, R., Goldthorpe, J.H. \& Portocarero, L. (1991). Intergenerational class mobility in three western European societies. British Journal of Sociology, 30, 415-441.

Ganzeboom, H.B.G., Graaf, P.M. de \& Treiman, D. (1992). A standard international socio-economic index of occupational status. Social Science Research, 21, 1-56.

Glebbeek, A. (1993). Perspectieven op loopbanen. Assen: Van Gorcum.

Goldthorpe, J.H. (2000). On sociology: Numbers, narratives, and the integration of research and theory. Oxford: Oxford University Press.

Grip, A. de, Hoevenberg, J. \& Willems, E. (1997). Atypical employment in the European Union. International Labour Review, 136, 49-71.

Kalleberg, A. (2000). Nonstandard employment relations: Part-time, temporary and contract work. Annual Review of Sociology, 26, 341-365. 
Kalleberg, A., Reskin, B. \& Hudson, K. (2000). Bad jobs in America: Standard and nonstandard employment relations and job quality in the United States. American Sociological Review, 65, 256-278.

Kleinknecht, A.H., Oostendorp, R.H. \& Pradhan, M.P. (1997). Patronen en economische effecten van flexibiliteit in de Nederlandse arbeidsverhoudingen: een exploratie op basis van de OSA vraagen aanbodpanels. WRR Voorstudies en Achtergronden, 99. Den Haag: SDU.

Maddala, G.S. (1983). Limited dependent and qualitative variables in econometrics. Cambridge: Cambridge University Press.

McGinnity, F., Mertens, A. \& Gundert, S. (2005). A bad start? Fixed-term contracts and the transition from education to work in West Germany. European Sociological Review, 21, 359374.

Meer, P. van der \& Wielers, R. (2001). The increased labour market participation of Dutch students. Work, Employment and Society, 15, 55-71.

Meulders, D., Plasman, R. \& Plasman, O. (1994). Atypical employment in the EC. Aldershot: Darthmouth.

Mills, M. \& Blossfeld, H.-P. (2005). Globalization, uncertainty and the early life course. A theoretical framework. In: H.-P. Blossfeld, E. Klijzing, M. Mills \& K. Kurz (red.). Globalization, uncertainty and youth in society (pp. 1-24). London/New York: Routledge.

Muffels, R., Dekker, R. \& Stancanelli, E. (1999). Een flexibele baan: opstap naar een vaste baan of eindstation? Sociale Wetenschappen, 42, 43-65.

Muffels, R.J.A. \& Luijkx, R. (2006). Globalization and male job mobility in European welfare states. In: H.-P. Blossfeld, M. Mills \& F. Bernardi (red.). Globalization, uncertainty and men's careers. An international comparison (pp. 38-74). Cheltenham: Edward Elgar.

OECD (1998). Employment Outlook 1998. Paris: Organisation for Economic Cooperation and Development.

OECD (1999). Employment Outlook 1999. Paris: Organisation for Economic Cooperation and Development.

OECD (2002). Employment Outlook 2002. Paris: Organisation for Economic Cooperation and Development.

Remery, C., Doorne-Huiskes, A. van \& Schippers, J. (2002). Labour market flexibility in the Netherlands: Looking for winners and losers. Work, Employment and Society, 16, 477-495.

ROA (2002). Schoolverlaters tussen onderwijs en arbeidsmarkt 2001. Maastricht: Researchcentrum voor Onderwijs en Arbeidsmarkt.

Salverda, W. (1992). Youth unemployment: Dynamics of the Dutch labour market 1955-1988. Groningen: Wolters-Noordhoff.

Scherer, S. (2004). Stepping-stones or traps? The consequences of labor market entry positions on future career in West Germany, Great Britain and Italy. Work, Employment and Society, 18, 369-394.

Shavit, Y. \& Müller, W. (2000). Vocational secondary education: Where diversion and where safety net? European Societies, 2, 29-50.

Steijn, B. (1999). De arbeidsmarktpositie van flexibele werknemers: bewijs van een gesegmenteerde arbeidsmarkt? Sociale Wetenschappen, 42, 90-105.

Steijn, B., Need, A. \& Gesthuizen, M. (2006). Well begun, half done? Long-term effects of labour market entry in the Netherlands, 1950-2000. Work, Employment and Society, 20, 453-472.

Stinchcombe, A.L. (1979). Social mobility in industrial labor markets. Acta Sociologica, 22, 271245.

Visser, J. (2002). The first part-time economy in the world: A model to be followed? Journal of European Social Policy, 12, 23-42.

Visser, J. \& Hemerijck, A. (1997). A Dutch miracle: Job growth, welfare reform and corporatism in the Netherlands. Amsterdam: Amsterdam University Press.

Vries, R. de \& Wolbers, M.H.J. (2005). Non-standard employment relations and wages among school leavers in the Netherlands. Work, Employment and Society, 19, 503-525.

Wilthagen, T. (1998). Flexicurity: A new paradigm for labour market policy reform? WZB discussion paper FS I 98-202. Berlin: Social Science Research Centre Berlin.

Wolbers, M.H.J. (2005a). Initial and further education: Substitutes or complements? Differences in continuing education and training over the life-course of European workers. International Review of Education, 51, 459-478.

Wolbers, M.H.J. (2005b). De arbeidsmarktintegratie van schoolverlaters in Europa. Tijdschrift voor Arbeidsvraagstukken, 21, 129-139. 